Janusz Mótka*

Kraków

\title{
Obecność myśli pedagogicznej w polskiej katechezie
}

W połowie XX wieku obserwowaliśmy w Kościele katolickim wyraźne ożywienie ruchu katechetycznego. Miało ono miejsce również na terenie naszego kraju. Swym zasięgiem obejmowało refleksję nad treściami przekazu katechetycznego, jak również zagadnieniami dydaktycznymi i pedagogicznymi. Efektem tej refleksji było wypracowanie nowego modelu nauczania religii, który został zawarty w Ramowym programie katechizacji w zakresie szkoły podstawowej oraz dwóch schematach szczegółowych (dwóch programach szczegółowych). Program ramowy obowiązywał do roku 1999 do wprowadzenia nowego systemu edukacji w Polsce.

Kluczową postacią dla odnowy modelu katechezy w Polsce był jezuita - ks. prof. dr hab. Jan Charytański (1922-2009). Zorganizował on zespół, przed którym stanęło zadanie opracowania nowych podręczników do nauczania religii ${ }^{1}$. Efektem prac zespołu kierowanego przez Jana Charytańskiego były serie podręczników dla ucznia oraz podręczników metodycz-

* Dr Janusz Mółka SJ jest pracownikiem Katedry Pedagogiki Ogólnej i Teorii Wychowania w Instytucje Nauk o Wychowaniu Akademii Ignatianum w Krakowie. Adres: Akademia Ignatianum w Krakowie, Instytut Nauk o Wychowaniu, ul. Kopernika 26, 31-501 Kraków; e-mail: janusz.molka@ignatianum.edu.pl.

1 Podobne założenia przyświecały także zespołowi, którym kierował ks. dr Edward Materski, późniejszy biskup. 
nych dla nauczyciela: Bóg z nami (część I-IV) i Katechizm religii katolickiej (część I-IV).

W artykule zajmiemy się omówieniem propozycji działań pedagogicznych, jakie wraz z wprowadzeniem Ramowego programu z 1971 roku pojawiły się i występowały w polskiej katechezie do czasu wprowadzenia reformy systemu oświaty w Polsce w 1999 roku. W szczególności postaramy się odpowiedzieć na pytanie o to, w jakim zakresie wykorzystano wiedzę pedagogiczną w podręcznikach adresowanych do uczniów oraz katechetów.

\section{Inspiracje dla odnowy myśli katechetycznej}

Wspomniana powyżej odnowa zainicjowana została przemianami, jakie zaszły w Kościele tuż przed rozpoczęciem Soboru Watykańskiego II (1962-1965), podczas jego trwania oraz w dobie wprowadzania jego osiągnięć do praktyki duszpasterskiej. Chodzi przede wszystkim o kongresy katechetyczne organizowane między innymi w Nijmegen (1959), Eichstätt (1960), Bangkoku (1962), Katigondo (1964), Manili (1967), Medellin (1968). Ich uczestnicy podejmowali refleksję nad sposobami przekazu treści wiary katolickiej. O ile początkowo dominowały tendencje ich przekazu w myśl zasad ruchu odnowy materialno-kerygmatycznej, to z czasem coraz wyraźniej do głosu dochodziły trendy domagające się większego nachylenia antropologicznego w przekazie tych treści. Chodziło o dostosowanie przepowiadania Słowa Bożego do uwarunkowań sytuacji życiowej odbiorcy, szczególnie jego uwarunkowań kulturowych. Trendy te Klemens Tilmann nazywał katechezą egzystencjalną, Bruno Dreher katechezą indukcyjną, a katechetycy francuscy określali katechezą antropologiczną ${ }^{2}$. We wszystkich tych ujęciach poszukiwano możliwości dostosowania treści wiary do możliwości odbiorcy, jego zainteresowań i dążeń. Sugerowano przy tym potrzebę większego zwracania uwagi na środowisko społeczne katechizowanych i ich życiowe problemy. Innymi słowy w pojawiających się trendach akcentowano potrzebę lepszego poznania świata katechizowanych. Działania te doprowadziły do przekonania, że katecheza powinna być nie tylko biblijna, kerygmatyczno-liturgiczna, eklezjalna, ale również antropologiczna. Wypracowane za-

2 Władysław Kubik, „Proces przemian w polskiej katechetyce drugiej połowy XX wieku”, w: Kerygma. Biblia. Katecheza, red. Ryszard Czekalski (Warszawa: Wydawnictwo Uniwersytetu Kardynała Wyszyńskiego, 2012), 59-60. 
łożenia ujęto w tak zwanej podwójnej zasadzie wierności Bogu i wierności człowiekowi ${ }^{3}$.

Trendy te do Polski docierały z pewnym opóźnieniem, czego przyczyn należy doszukiwać się w poważnych utrudnieniach w nawiązywaniu kontaktów z katechetykami Europy Zachodniej. Nie bez znaczenia były też straty kadrowe poniesione podczas drugiej wojny światowej, brak dostępu do literatury katechetycznej, poniszczone księgozbiory, a ponadto upolitycznienie systemu oświatowego oraz walka światopoglądowa z Kościołem, czego efektem było między innymi zamykanie „szkół prywatnych - w tym kościelnych i zakonnych, usuwanie religii z nauczania szkolnego, a podczas tworzonych treści programowych pomijano zagadnienia związane z religią katolicką"”.

Jak zauważył ks. Władysław Kubik, po roku 1950 rozpoczął się w Polsce szczególnie niekorzystny okres dla twórczości w dziedzinie teorii katechetycznej. Towarzystwo Przyjaciół Dzieci (TPD), zakładające całkowitą świeckość szkoły w PRL, obejmowało swoim patronatem coraz większą ilość szkół. W związku z tym w pedagogice szkolnej zaczęto wdrażać tak zwany naukowy pogląd na świat oparty na założeniach filozofii marksistowskiej. Ukazywano człowieka jako istotę wyłącznie materialną, choć obdarzoną świadomością. Zdaniem marksistów ludzka osobowość była wyłącznie funkcją stosunków społecznych. Życie człowieka nie miało żadnego celu pozaziemskiego oraz odniesienia do transcendencji, czyli kończyło się wraz ze śmiercią. W wyniku tej polityki państwa wobec Kościoła zaczęto równolegle do działań szkoły organizować nauczanie religii przy parafiach. Inicjatywę tę zapoczątkował Wydział Nauki Katolickiej przy Kurii Metropolitalnej w Warszawie, który w 1950 roku wydał zarządzenie organizowania punktów katechetycznych w parafiach. Dla potrzeb tej działalności opracowano program nauki religii poza szkołą ${ }^{5}$ Cytowany Władysław Kubik zauważa, że z nowym programem z 1958 roku wiązało się opracowanie i druk nowych podręczników. Jednak od strony metody nauczania nadal dominowała w Polsce metoda monachijska ${ }^{6}$, która opierała się o teorię stopni formalnych.

3 Antoni Długosz, Beata Stypułkowska, Wprowadzenie do dydaktyki biblijnej (Kraków: Wydawnictwo Naukowe Papieskiej Akademii Teologicznej, 2000), 76-84.

${ }^{4}$ Wojciech Cichosz, Możliwości dialogu wychowania chrześcijańskiego ze wspótczesna edukacja polska (Pelplin: Wydawnictwo „Bernardinum”, 2013), 43-44.

5 Kubik, „Proces”, 62.

${ }^{6}$ Szerzej w literaturze katechetycznej na temat teorii stopni formalnych pisze m.in.: Władysław Kubik, Rozwój myśli dydaktycznej w polskiej literaturze katechetycznej w latach 1895-1970 (Warszawa: Akademia Teologii Katolickiej, 1987), 101-165. 
Polscy katechetycy lat pięćdziesiątych, ks. Józef Łapot (1903-1962), a przede wszystkim ks. Józef Dajczak (1894-1966), zapoznawali katechetów z dorobkiem różnych nurtów nowej szkoły i sposobami ujmowania procesu nauczania. Obaj jednak preferowali układ lekcji i przebieg nauczania według wspomnianych stopni formalnych, chociaż proponowali, aby niektóre postulaty nowego wychowania, jak postulaty liczenia się z wiekiem uczniów, rozbudzenia ich sfery uczuć i woli, prowadzenia do konkretnego czynu, katecheci uwzględniali podczas prowadzonej katechizacji. Do znaczących w tamtym okresie katechetyków należy jeszcze dołączyć ks. Walentego Gadowskiego (1861-1956), ks. Wincentego Zaleskiego (1913-1983), ks. Mariana Finkego (1906-1986).

W opracowywanych dla potrzeb lat pięćdziesiątych i sześćdziesiątych materiałach katechetycznych dominowały metody oparte na słowie, czyli wykład, opowiadanie i pogadanka ${ }^{7}$. W tym zakresie wprowadzenie wielu zmian zawdzięczamy ks. Józefowi Wojtukiewiczowi (1901-1989). Do proponowanych podczas katechezy zajęć wprowadził metodę przeżyciowo-czynną, polegającą na podejmowaniu różnego rodzaju zajęć aktywizujących, na przykład: kolorowania obrazków, wycinania, wklejania, rozmowy. Posługiwanie się metodą czynną było możliwe dzięki stosowaniu różnorodnych pomocy przeznaczonych dla katechety i dla ucznia ${ }^{8}$.

\section{Zasadnicze zmiany w myśleniu o katechizacji}

Sobór Watykański II nie opracował żadnego dokumentu odnoszącego się do katechizacji, niemniej podnoszone w czasie jego trwania problemy zainspirowały do refleksji nad modelem katechezy. W Polsce nowe myślenie o katechezie zainicjował wspomniany ks. Jan Charytański. Jego inicjatywy są inspiracją do prowadzonej po dziś dzień refleksji katechetycznej. Swym zasięgiem obejmuje ona zarówno treści katechizacji, jej cele, a także metody i formy jej przeprowadzenia. W wyniku rzetelnie podjętej refleksji teologicznej ukazał się szereg dokumentów katechetycznych9 .

7 Kubik, „Proces”, 62-65.

8 Barbara Rozen, „Wojtukiewicz Józef (1901-1989)”, w: Słownik katechetyków polskich XX wieku, red. Ryszard Czekalski (Warszawa: Wydawnictwo Salezjańskie, 2003), 274-276.

9 Zbigniew Marek, Podstawy i założenia katechetyki fundamentalnej (Kraków: Wydawnictwo WAM, 2007), 36-38; Jan Charytański, „Inspiracje soborowe w katechetyce”, w: 
Jak zauważyliśmy, od końca lat pięćdziesiątych do początku lat siedemdziesiątych w Polsce w podejmowanych dyskusjach, poszukiwaniach i wypracowywanych programach nauczania akcentowano przekonanie, że ucznia na każdym etapie rozwojowym można uczyć podstaw każdego przedmiotu, przy zastosowaniu odpowiednich form i metod dostosowanych do jego możliwości percepcyjnych. Zaczęto doceniać rolę myślenia intuicyjnego, podkreślano znaczenie motywacji uczenia się, wyzwalania zainteresowań, korzystania z pomocy dydaktycznych, środków audiowizualnych ${ }^{10}$.

Ważną inicjatywą tamtych lat było powołanie do życia Podkomisji Katechizmowej przez Plenarną Konferencję Episkopatu Polski na wniosek Komisji Katechetycznej Episkopatu w dniu 12 stycznia 1961 roku. Głównym zadaniem Podkomisji było przygotowanie jednolitego ogólnopolskiego katechizmu. Równolegle do prac Podkomisji Katechizmowej, która zajęła się opracowaniem podręcznika-katechizmu dla dzieci i młodzieży, przez członka Podkomisji Katechizmowej, ks. Jana Charytańskiego, została zorganizowana grupa, początkowo złożona z jezuitów, której zadaniem było opracowanie podręczników do nauki religii dla dzieci młodszych, początkowych klas szkolnych.

W wyniku podjętych przez Podkomisję Katechizmową prac opracowano jednolity katechizm pod nazwą Katechizm Religii Katolickiej, tom I i II, wydany w 1968 roku nakładem Księgarni św. Wojciecha w Poznaniu. W tym samym roku w Wydawnictwie Apostolstwa Modlitwy w Krakowie wydano drukiem dwa pierwsze tomiki podręczników Bóg z nami, przeznaczone dla pierwszych czterech lat katechizacji ${ }^{11}$. Charakterystyczne dla obu serii było nowoczesne przekazywanie treści wiary, które brało pod uwagę jej odbiorcę - ucznia, a także i to, że poza podręcznikami dla ucznia opracowano materiały dla katechety. Poza treściami teologicznymi otrzymywali oni także wskazania dotyczące samego metodycznego przeprowadzenia katechezy, a nadto dodatkowy materiał przeznaczony do pracy edukacyjnej z rodzicami.

Szczególne zasługi w nowym myśleniu o katechizacji należy przypisać wspomnianemu jezuicie, Janowi Charytańskiemu, który jako członek Zespołu Komisji Katechizmowej starał się zaszczepić do polskiej katechezy myślenie Soboru Watykańskiego. Podejmowane przez niego wysiłki sprawiły, że uważany jest za jednego z prekursorów nurtu kerygmatycznego w Polsce.

Katecheza po Soborze Watykańskim II w świetle dokumentów Kościoła, t. 1, red. Władysław Kubik (Warszawa: Akademia Teologii Katolickiej, 1985), 13-44.

${ }^{10}$ Kubik, „Proces”, 65.

11 Tamże, 67. 
Zgodnie z założeniami tego nurtu podkreślał, że Boże objawienie stanowi centralną kategorię katechetyczną i źródło chrześcijańskiego przepowiadania. Był przekonany, że płaszczyzną spotkania Boga z człowiekiem, jakie ma miejsce podczas katechezy, jest dialog o charakterze biblijno-sakramentalnym, który prowadzi człowieka do dojrzałości wiary.

W późniejszym okresie twórczości Jan Charytański swą uwagę skupiał wokół zagadnień katechezy antropologicznej, czego wyrazem są jego publikacje teoretyczne, jak również tworzone pod jego kierunkiem materiały katechetyczne. W proponowanych treściach w podręcznikach dla młodzieży w latach 70. i 80. wskazywał na konkretną pomoc w rozwiązywaniu codziennych ludzkich problemów w duchu Ewangelii. Chodziło mu o to, aby dzięki katechezie przygotować chrześcijanina do życia we współczesnym świecie, przyczynić się do kształtowania ludzi wolnych, odpowiedzialnych, gotowych do podejmowania właściwych wyborów ${ }^{12}$. Andrzej Offmański trafnie podsumowuje obszar zainteresowań Jana Charytańskiego, stwierdzając: „Personalistyczna koncepcja katechezy spotkań, której owoc stanowi odnowa człowieczeństwa i chrześcijaństwa, to wynik doświadczenia religijnego i poszukiwań współczesnego człowieka, a zawiera w sobie elementy katechezy kerygmatycznej, antropologicznej, integralnej, ale też osobiste doświadczenie wiary" 13 .

Prezentacja sylwetki wybitnego polskiego katechetyka pozwala wskazać na główne trendy w myśleniu i nauczaniu katechetycznym w Polsce w drugiej połowie XX wieku. Z pomocą przychodzi również refleksja współpracownika Jana Charytańskiego, przywoływanego wcześniej jezuity Władysława Kubika. Pisze on, że autorzy podręczników do nauki religii dla uczniów oraz podręczników metodycznych dla katechetów świadomie kierowali się postulatami pedagogiki i dydaktyki szkolnej. Jednak zdawali sobie sprawę, że

katechezy nie można sprowadzać wyłącznie do procesu nauczania-uczenia się, a pracy katechety zawężać do wymagań dydaktyczno-wychowawczych szkoły. Świadomi zwłaszcza roli pośrednika, jaka przypada w udziale katechecie, starali się mu dostarczać wskazań i sposobów pracy, które pomagałyby mu stawać

${ }_{12}$ Andrzej Offmański, „Charytański Jan”, w: Słownik katechetyków polskich XX wieku, red. Ryszard Czekalski (Warszawa: Wydawnictwo Salezjańskie, 2003), 33-38.

13 Andrzej Offmański, „Z pokolenia nieustannie poszukujących. Wkład Jana Charytańskiego SJ w odnowę i rozwój polskiej katechezy", w: Sto lat polskiej katechezy. Wkład wybitnych polskich katechetyków w odnowę i rozwój polskiej katechezy, red. Ryszard Czekalski (Kraków: Wydawnictwo WAM, 2001), 174. 
razem z uczniami wobec Boga przemawiającego zarówno do nauczających, jak i uczących się oraz ułatwiały odkrywanie właściwego wezwania zawartego w słowie Bożym i dawanie na nie odpowiedzi ${ }^{14}$.

Do takiego rozwoju myśli katechetycznej przyczyniły się publikowane wówczas dokumenty katechetyczne ${ }^{15}$, dzięki którym coraz bardziej oczywiste stawało się przekonanie o konieczności uwzględniania w katechezie zasady wierności Bogu i wierności człowiekowi. W przypadku wierności Bogu chodzi o otwarcie człowieka na Boga oraz umożliwienie mu komunikacji z Bogiem. Zasada ta domaga się dowartościowania Bożego Objawienia, które odsłania przed człowiekiem przede wszystkim nowy sens jego życia. Trzeba pamiętać, że dzięki Bożemu Objawieniu człowiek jest w stanie odkrywać sens zbawczej interwencji Boga. Na tej drodze dochodzi człowiek też do przejmowania za własną tajemnicy Boga i nabywania zdolności interpretowania w jej świetle życiowych wydarzeń. Stąd też katecheza, która zamierza być wierna Bogu, nie może pomijać kwestii związanych z przekazem tajemnicy Boga. Natomiast drugi człon tej zasady - wierność człowiekowi eksponuje możliwości i potrzeby religijne człowieka. Zwrot ten wskazuje na konieczność liczenia się z procesami rozwoju człowieka, które umożliwiają mu odkrywanie i dochodzenie do źródeł życia - Boga, uwzględniając jego możliwości nawiązywania z Nim relacji. Wszystko to pokazuje, że zasada wierności Bogu i wierności człowiekowi wymaga działań prowadzących do spotkania osób. Spotkanie takie ma miejsce wówczas, gdy obie osoby stają wobec siebie w relacji $\mathrm{Ja}^{-} \mathrm{Ty}^{16}$.

14 Kubik, „Proces”, 73.

15 Po 1971 roku do końca XX wieku ukazały się następujące dokumenty Urzędu Nauczycielskiego Kościoła dotyczące katechizacji: Kongregacja ds. Duchowieństwa: Ogólna instrukcja katechetyczna (11.04.1971); Paweł VI, Adhortacja apostolska o ewangelizacji w świecie współczesnym Evangelii nuntiandi (8.12.1974); Orędzie Synodu Biskupów do Ludu Bożego Współczesna katecheza zwłaszcza dzieci i młodzieży (1977); Jan Paweł II, Adhortacja apostolska o katechizacji w naszych czasach Catechesi tradendae (16.10.1979); Międzynarodowa Rady ds. Katechezy, Katecheza dorosłych we wspólnocie chrześcijańskiej (1988); Katechizm Kościoła Katolickiego (8.12.1992); Kongregacja ds. Duchowieństwa, Dyrektorium ogólne o katechizacji (15.08.1997). Por. Ryszard Czekalski, „Historia katechezy przedmiotem wykładów z katechetyki. Zarys historii katechezy", w: Abyśmy podtrzymywali nadzieję. Księga Jubileuszowe ku czci ks. prof. Romana Murawskiego SDB, red. Piotr Tomasik (Warszawa: Wydawnictwo Salezjańskie, 2005), 72-73.

16 Por. Andrzej Hajduk, Zbigniew Marek, „Zasada wierności Bogu i wierności człowiekowi w polskiej katechezie", Seminare 17 (2001): 33-46. 


\section{Charakterystyka przemian w polskiej katechezie lat 1971-1999}

Charakteryzując obecność myśli pedagogicznej w polskiej katechezie, nie sposób obszernie omówić całość zagadnienia w kilkustronicowym opracowaniu. Zwrócimy zatem uwagę na wybrane aspekty myślenia pedagogicznego dla integralnego kształtowania osoby ludzkiej w procesie nauczania katechetycznego. W 1971 roku ogłoszony został nowy program katechizacji. Redakcję programu ramowego dla uczniów klas od I do VIII szkoły podstawowej przygotowali s. Halina Płaska oraz ks. Jan Charytański. Natomiast dla młodzieży szkół ponadpodstawowych przygotowała grupa osób pod przewodnictwem ówczesnego redaktora naczelnego czasopisma Katecheta, ks. Mariana Finkego. Dodajmy, że obok programu ramowego Komisja Katechetyczna Episkopatu Polski przyjęła również dwa schematy szczegółowe do Ramowego programu katechizacji. Jednym z nich był schemat szczegółowy opracowany przez przedstawicieli ośrodków katechetycznych w Warszawie i Kielcach. Do realizacji tej wersji pomocą służyły podręczniki dla uczniów Mój katechizm oraz Chrystus Prawdą oraz materiały pomocnicze drukowane systemem powielaczowym ${ }^{17}$. Drugą wersję programu szczegółowego przygotował zespół pod kierunkiem Jan Charytańskiego. Konkretną realizację tego schematu stanowiły wspomniane wcześniej podręczniki dla ucznia Bóg z nami i Katechizm religii katolickiej oraz równolegle do nich podręczniki metodyczne dla katechety ${ }^{18}$. Okres ten Anna Walulik podsumowuje w następujący sposób:

Nauczanie religii w szkole i przy kościele, podobnie jak każde inne nauczanie szkolne, prowadzone było według ustalonych programów. Celem było rozłożenie i uporządkowanie treści przeznaczonych do nauczania. Zgodnie z definicją programu nauczania istniała korelacja pomiędzy założeniami programów a treścią nauki. Dlatego reformie i zmianom w szkolnictwie zwykle towarzyszyła

17 Kubik, Rozwój, 171.

18 Bóg z nami, cz. I i II, Kraków 1968; Bóg z nami, cz. I i II, podręcznik dla katechety, red. Jan Charytański, Warszawa 1971; cz. III, Warszawa 1972; cz. IV, Warszawa 1974; Katechizm religii katolickiej, tom I i II, Poznań 1968; cz. III i IV, Kraków 1971 (oraz kolejne wydania); Podręcznik metodyczny do „Katechizmu religii katolickiej”, red. Jan Charytański, Władysław Kubik, cz. I, Warszawa 1976; cz. II, Warszawa 1978; cz. III i IV, Warszawa 1980. 
przebudowa programów. W polskiej katechezie proces ten następował wolno, jakby nie liczył się z koniecznością ich gruntownej przemiany ${ }^{19}$.

I dodaje dalej: „Zmiany, jakie wniósł program z roku 1971, dotyczyły głównie treści katechezy, zgodnie z założeniami współczesnej mu myśli katechetycznej. Takie ujęcie pozwoliło dowartościować biblijne i liturgiczne źródła katechezy. Jednak zbyt mocny akcent kerygmatyczny tego programu stawiał w cieniu doświadczenia życiowe wychowanków"20.

Uzupełnijmy przedstawiony wyżej wywód spostrzeżeniem, że w poszukiwaniach kierunku myśli i tworzeniu materiałów będących próbą integracji różnych nurtów katechetycznych i osiągnięć nauk pomocniczych, ze szczególnym uwzględnieniem dydaktyki i pedagogiki, na uwagę zasługują jeszcze dwa ważne wydarzenia w omawianym przez nas okresie. Pierwsze o zasięgu ogólnokościelnym to opublikowanie Ogólnej instrukcji katechetycznej w Rzymie w 1971 roku. Głównym celem Instrukcji było utrwalenie w katechezie dorobku Soboru Watykańskiego II oraz potwierdzenie słusznych postulatów nurtu odnowy materialno-kerygmatycznej i orientacji antropologicznej. Natomiast drugim znaczącym wydarzeniem, tym razem dla katechezy w Polsce, było zorganizowanie sympozjum katechetycznego w dniach 14-16 czerwca 1972 roku. Sympozjum zgromadziło liczących się profesorów katechetyki oraz wizytatorów diecezjalnych wraz z przewodniczącym Komisji Katechetycznej Episkopatu, ks. bpem Jerzym Strobą. Przeprowadzona wówczas refleksja dokonała podsumowania dotychczasowych poszukiwań oraz ukierunkowała dalszy rozwój katechetyki na terenie naszego kraju ${ }^{21}$.

Na kierunek rozwoju myśli katechetycznej, rewizję celów, treści i metod katechezy, rzuciła światło ogłoszona przez papieża Pawła VI adhortacja apostolska o ewangelizacji w świecie współczesnym Evangelii nuntiandi z 1974 roku. Dokument ten określał stosunek ewangelizacji do katechizacji, co spowodowało przyjrzenie się zasadniczym kwestiom odnoszącym się do przepowiadania Słowa Bożego podczas katechezy i udzielania odpowiedzi poprzez świadectwo życia. Doniosłe znaczenie dla dzieła katechizacji przypisuje się jednak zwołanemu w 1977 roku Synodowi Biskupów, w wyniku którego została ogłoszona adhortacja apostolska o katechizacji w naszych

19 Anna Walulik, Katecheza inicjacyjna w polskich katechizmach (1945-1990) (Kraków: Wydawnictwo WAM, 2002), 104-105.

20 Tamże, 105.

${ }^{21}$ Kubik, Rozwój, 171-172. 
czasach Catechesi tradendae, podpisana przez papieża Jana Pawła II w 1979 roku. Dokument papieski poruszył najważniejsze problemy współczesnej katechezy, omówił jej rozwój, zadania, treści, źródła i cele, sposoby i formy jej realizacji oraz zwracał uwagę na uczestników katechezy na poszczególnych etapach rozwoju człowieka. Jednocześnie dokument wskazywał na jedno z podstawowych zadań katechezy, jakim jest wzmacnianie tożsamości chrześcijańskiej. Stąd Tadeusz Nosek stwierdza: „Wymaga to bez wątpienia, aby katecheza umacniała chrześcijan w ich własnej tożsamości i aby sama była stale chroniona od napotykanych niejednokrotnie wątpliwości, niepewności i niedorzeczności"22.

Ostatnim natomiast ważnym dokumentem XX wieku odnoszącym się do katechizacji było Dyrektorium ogólne o katechizacji wydane w 1997 roku. Dokument ten szczególny akcent położył między innymi na potrzebę budzenia i ożywiania doświadczenia wiary, otwierania na ludzkie i chrześcijańskie wartości oraz wychowania katechizowanych do współdziałania i współodpowiedzialności za wspólnotę Kościoła i otaczający świat ${ }^{23}$.

Osiągnięcia uzyskiwane $\mathrm{w}$ dydaktyce i pedagogice w ostatnich dziesięcioleciach minionego stulecia pozwoliły na uwzględnianie ich również na gruncie katechetyki i katechezy. Zaczęto doceniać w procesie nauczenia dzieci i młodzieży istotne aspekty uzyskiwania efektów edukacyjnych, pogłębiając i rozwijając o elementy religijne, charakterystyczne dla kształcenia i formacji katechetycznej. Dlatego w wydanych dokumentach i opracowanych publikacjach z katechetyki należy poszukiwać inspiracji myśli pedagogicznej w nauczaniu katechetycznym. Obecnie zasygnalizujemy jedynie niektóre wybrane zagadnienia z tym związane, gdyż nie jest łatwo wyczerpująco określić całościowy zakres i treść nauczania i wychowania w niniejszym opracowaniu.

Ogólne zasady katechezy dzieci i młodzieży w sposób precyzyjny konkretyzuje wspominane Dyrektorium ogólne o katechizacji z 1997 roku. Dokument ten, po pierwsze, uwrażliwia na uwzględnianie w procesie naucza-

22 Tadeusz Nosek, „Katechetyczne umacniane i rozwijanie tożsamości chrześcijańskiej”, w: Pedagogika wiary. Książka dedykowana księdzu Profesorowi Zbigniewowi Markowi SJ w 60. rocznicę urodzin i 35. rocznicę kapłaństwa, red. Andrzej Hajduk, Janusz Mółka (Kraków: Wydawnictwo WAM, 2007), 312.

${ }^{23}$ Dyrektorium ogólnemu o katechizacji poświęcona została m.in. publikacja, która składa się z referatów wygłoszonych podczas Ogólnopolskiego Sympozjum Wykładowców Katechetyki i Pedagogiki Wyższych Seminariów Duchownych w Polsce, w Częstochowie, w dniach 28-29.09.1998 r. Zob. Katecheza Kościoła w świecie. Dyrektorium ogólne o katechizacji (Kraków: Wydawnictwo WAM, 1999). 
nia i wychowania różnorodności sytuacji religijnej i różnego poziomu wiary dzieci i młodzieży. W związku z tym dokument przypomina, aby prowadzone duszpasterstwo nie traktowało uczniów i wychowanków jako zhomogenizowanej czy jednolitej grupy, lecz traktowało na sposób podmiotowy i indywidualny. Należy przy tym pamiętać, zaznaczono w dokumencie, że pod względem odniesień do wiary każdy domaga się specyficznej pomocy, która zależy od wieku, cech pokoleniowych, potrzeb duchowych czy też związanych z poziomem religijności. Kolejną sprawą, na którą wskazuje dokument, jest realizowanie katechezy w kontekście całego duszpasterstwa, czyli obejmującego na przykład uczestniczenie w sprawowanych sakramentach, zaangażowanie w grupach apostolskich i wspólnotach religijnych. Ważną kwestią $\mathrm{w}$ procesie nauczania katechetycznego jest korzystanie $\mathrm{z}$ danych dostarczanych przez nauki o człowieku i wychowaniu, pamiętając jednak o tym, aby kierować się prawem do ewangelicznego osądu tych propozycji. Należy także pamiętać, że katecheza powinna polegać na współpracy katechety i katechizowanych ${ }^{24}$.

W procesie nauczania i uczenia się należy ponadto uwzględniać ważne etapy. W pierwszej kolejności należy zaznajomić katechizowanych z celem pracy, aby motywował uczenie się. Następnie trzeba kierować zdobywaniem jasnych pojęć religijnych, aby uczniowie mogli się nimi samodzielnie i poprawnie posługiwać. Ważne jest też to, aby katechizowanych uczyć myśleć na gruncie prawd i wartości płynących z wiary. Nieodzowne jest również to, aby zadbać o odkrywanie przez uczniów związku między poznawanymi prawdami wiary a ich osobistym życiem. Chodzi także o to, aby uczestnicy nauczania religii nie tylko chwilowo zapamiętali przekazywane treści, ale je utrwalili i stosowali na co dzień. W procesie nauczania i uczenia się istotne jest okazywanie pomocy we wprowadzaniu w praktykę życia wiedzy i wartości, jak również kształtowanie odpowiednich umiejętności. Ważnym elementem tego procesu jest uczenie refleksji nad przebytą drogą osobistego rozwoju, osiągniętymi sukcesami i porażkami w stosunku do wyznaczonego celu ${ }^{25}$.

Na podstawie zasygnalizowanej problematyki można uznać, że coraz wyraźniej uświadamiano sobie, a następnie wcielano w praktykę nauczania katechetycznego, to co wcześniej (lub równolegle) było realizowane w pedagogice i dydaktyce szkolnej, współzależność i powiązanie pomiędzy celami, treścią i metodami. Występująca korelacja między wymienionymi elemen-

${ }^{24}$ Piotr Tomasik, „Podręcznik w edukacji religijnej młodzieży”, w: Dydaktyka w stużbie katechezy, red. Stanisław Dziekoński (Kraków: Wydawnictwo WAM, 2002), 249.

${ }^{25}$ Kubik, „Proces”, 78. 
tami wpływa w sposób zdecydowany na przebieg zarówno samego procesu uczenia się i nauczania, jak również, a może przede wszystkim, na kształt integralnego i holistycznego kształcenia i wychowania młodego pokolenia. W końcu dopowiedzmy, że proces ten jest kontynuowany w wielorakich wymiarach. Pierwszym są tworzone nowe dokumenty Kościoła w Polsce poświęcone katechezie. Są nimi: Dyrektorium katechetyczne Kościoła katolickiego w Polsce (2001), Podstawa programowa katechezy Kościoła katolickiego w Polsce (2001) oraz Podstawa programowa katechezy Kościoła katolickiego w Polsce (2010). Jednocześnie wypracowano także korelujące z tymi dokumentami programy nauczania religii w szkole. Nie bez znaczenia jest też prowadzona refleksja nad istotą katechezy i jej uwarunkowaniami w Polsce przez współczesnych katechetyków. Nie sposób w tym miejscu wymienić wszystkich znaczących przedstawicieli, jednak obok wspomnianych już postaci warto przywołać: Mieczysława Majewskiego, Romana Murawskiego, bpa Antoniego Długosza, Władysława Kubika, Stanisława Kulpaczyńskiego, a z początkiem dwudziestego pierwszego wieku Zbigniewa Marka, Kazimierza Misiaszka, Ryszarda Czekalskiego, Stanisława Dziekońskiego, Piotra Tomasika ${ }^{26}$.

Reasumując przedstawioną problematykę, warte przytoczenia są słowa Jerzego Bagrowicza:

Rozwój katechetyki jako nauki pod koniec XX wieku związany był z przemianami cywilizacyjnymi, szczególnie procesami pluralizacji i laicyzacji życia. Potrzeba studium nad religijnością współczesnego człowieka przyniosła zainteresowanie odbiorcą katechezy i samą strukturę katechetyki przesunęła bardziej w kierunku poszukiwań i studiów naturalnych uwarunkowań realizacji nauczania religijnego, szczególnie w nurcie antropologicznym katechezy. Pluralizm form życia religijnego wskazuje także na potrzebę studiów katechetycznych nad pytaniami o wyznaniowy czy ogólnokulturowy charakter przekazu religijnego, o ekumeniczną postawę współczesnego chrześcijanina ${ }^{27}$.

26 Zob. Bibliografia katechetyczna 1945-1995, oprac. Roman Murawski, Ryszard Czekalski, Jacek Tochmański (Warszawa: Wydawnictwo Naukowe UKSW, 1999); Bibliografia katechetyczna 1996-2000, oprac. Ryszard Czekalski, Roman Murawski (Warszawa: Wydawnictwo Naukowe UKSW, 2002); Stownik katechetyków polskich XX wieku, red. Ryszard Czekalski (Warszawa: Wydawnictwo Salezjańskie, 2003); Teologu polski, co sądzisz o swojej twórczości?, red. Stanisław Celestyn Napiórkowski (Niepokalanów: Wydawnictwo Ojców Franciszkanów, 2007).

27 Jerzy Bagrowicz, „Pedagogika chrześcijańska - pedagogika religii (religijna) - katechetyka. Podobieństwa i różnice”, w: Abyśmy podtrzymywali nadzieję. Księga Jubileuszowe 
W zasygnalizowanym kontekście korelacji myśli pedagogicznej z myślą katechetyczną należy jeszcze nadmienić, że do rozwoju chrześcijańskiej, katolickiej myśli pedagogicznej przyczyniło się wielu teoretyków wychowania: Stanisław Podoleński, Józef Mirski, Barbara Żulińska, Karol Górski, Zygmunt Bielawski, Jacek Woroniecki, Franciszek Blachnicki, Feliks Wojciech Bednarski, Stefan Kunowski, Józef Wilk, Janusz Tarnowski, Teresa Kukołowicz i wielu innych ${ }^{28}$. Wskazywali oni, że ideałem nowego człowieka w wychowaniu jest doskonały chrześcijanin, świadomy celu i przeznaczenia, naśladujący wzór życia i postępowania w osobie Jezusa Chrystusa, otwarty na świat wartości oraz wrażliwy na współczesne sprawy i problemy codziennego życia. Podkreślali, że podstawę wychowania chrześcijańskiego stanowi formacja religijno-moralna oparta na miłości Boga i bliźniego. Trafnie ujmuje tę prawdę Alina Rynio:

Człowiek i jego wychowanie widziane jest całościowo w perspektywie metafizycznej, egzystencjalno-filozoficznie i psychologicznie. Uwzględnienie tych perspektyw gwarantuje pełny rozwój osoby ludzkiej jako członka danej społeczności i stopniowe wprowadzanie go na drodze wychowania i samowychowania w tajemnicę zbawienia. Katolicka myśl pedagogiczna wychowanie ujmuje najczęściej w kategorii wychowania personalistycznego. Uwzględniając zaś organiczny związek czynnika nadprzyrodzonego i naturalnego, wskazuje na integralny charakter wychowania chrześcijańskiego ${ }^{29}$.

\section{$* * *$}

Zakreślona problematyka $\mathrm{w}$ niniejszej prezentacji z konieczności nie wyczerpuje ogromu dokonanych w tym czasie przemyśleń, refleksji, analiz naukowych i propozycji praktycznego nauczania w dziedzinie polskiej katechezy. Od tamtego okresu do chwili obecnej opublikowano ponadto znaczące dokumenty, jak na przykład: wspomniane polskie wydanie Dyrektorium katechetycznego, Podstawe programowa katechezy Kościoła katolickiego $w$ Polsce oraz Program nauczania religii. Przede wszystkim została wpro-

ku czci ks. prof. Romana Murawskiego SDB, red. Piotr Tomasik (Warszawa: Wydawnictwo Salezjańskie, 2005), 44.

28 Zob. Janina Kostkiewicz, Kierunki i koncepcje pedagogiki katolickiej w Polsce 1918-1939 (Kraków: Oficyna Wydawnicza „Impuls”, 2013).

${ }^{29}$ Alina Rynio, „Katolicka myśl pedagogiczna. Próba syntezy”, w: Pedagogika katolicka. Zagadnienia wybrane, red. Alina Rynio (Stalowa Wola: Oficyna Wydawnicza Fundacji Uniwersyteckiej w Stalowej Woli, 1999), 415. 
wadzona reforma oświaty w 1999 roku, która zainspirowała opracowanie nowych programów i podręczników do nauczania religii. Przed polską katechezą również obecnie pojawiają się nowe zadania i oczekiwania w kontekście zapowiedzianej i wdrażanej od nowego roku szkolnego 2017 reformy oświaty przywracającej ośmioletnią szkołę podstawową, czteroletnie licea, pięcioletnie technika oraz zawodowe szkoły branżowe. Zasygnalizowane dokonania w przeszłości pokazują jednak, że zawsze znajdą się ludzie, którym będzie leżała troska o solidne i rzetelne nauczanie i wychowanie młodego pokolenia. Można zatem żywić nadzieję, że współcześnie też znajdą się osoby odpowiedzialne i mądre, które podejmą się czekających nas nowych wyzwań i zadań do zrealizowania.

\section{The Presence of Pedagogical Thought in Polish Catechesis (Summary)}

In the middle of the twentieth century we observed a clear revival of the catechetical movement in the Catholic Church. It also took place in our country. Its scope included reflection on the content of the catechetical message as well as on didactic and pedagogical issues. The result of this reflection was the development of a new model of religious instruction. Therefore, in this article we will focus on the crucial aspects of pedagogical thinking important for the integral education and development of the human person in the process of catechetical instruction. Our analysis will focus on the inspiration and fundamental changes that took place in the Polish catechesis from the new catechetical program announced in 1971 till the reform of the education system in Poland in 1999.

Keywords: catechesis; catechetics; pedagogy; didactics; religious education.

\section{Obecność myśli pedagogicznej w polskiej katechezie (Streszczenie)}

W połowie XX wieku obserwowaliśmy w Kościele katolickim wyraźne ożywienie ruchu katechetycznego. Miało ono miejsce również na terenie naszego kraju. Swym zasięgiem objęło refleksję nad treściami przekazu katechetycznego, jak również zagadnieniami dydaktycznymi i pedagogicznymi. Efektem tej refleksji było wypracowanie nowego modelu nauczania religii. W niniejszym artykule skupimy uwagę na wybranych aspektach myślenia pedagogicznego, ważnych dla integralne- 
go kształtowania i rozwoju ludzkiej osoby w procesie nauczania katechetycznego. Przeprowadzoną analizę skoncentrujemy wokół inspiracji oraz zasadniczych przemian, jakie dokonywały się w polskiej katechezie od nowego programu katechizacji z 1971 roku do wprowadzenia reformy systemu oświaty w Polsce w 1999 roku.

Słowa kluczowe: katecheza; katechetyka; pedagogika; dydaktyka; edukacja religijna.

\section{Bibliografia}

Bagrowicz, Jerzy. „Pedagogika chrześcijańska - pedagogika religii (religijna) - katechetyka. Podobieństwa i różnice". W: Abyśmy podtrzymywali nadzieję. Księga Jubileuszowe ku czci ks. prof. Romana Murawskiego SDB, red. Piotr Tomasik, 28-52. Warszawa: Wydawnictwo Salezjańskie, 2005.

Bibliografia Katechetyczna 1945-1995, oprac. Roman Murawski, Ryszard Czekalski, Jacek Tochmański. Warszawa: Wydawnictwo Naukowe UKSW, 1999.

Bibliografia Katechetyczna 1996-2000, red. Ryszard Czekalski, Roman Murawski. Warszawa: Wydawnictwo Naukowe UKSW, 2002.

Charytański, Jan. „Inspiracje soborowe w katechetyce”. W: Katecheza po Soborze Watykańskim II w świetle dokumentów Kościoła, t. 1, red. Władysław Kubik, 13-44. Warszawa: Akademia Teologii Katolickiej, 1985.

Charytański, Jan. Rzeczywistość miłości w Katechizmie Kościoła Katolickiego. Kraków: Wydawnictwo WAM, 1998.

Cichosz, Wojciech. Możliwości dialogu wychowania chrześcijańskiego ze wspótczesna edukacja polska. Pelplin: Wydawnictwo „Bernardinum”, 2013.

Czekalski, Ryszard. „Historia katechezy przedmiotem wykładów z katechetyki. Zarys historii katechezy". W: Abyśmy podtrzymywali nadzieję. Księga Jubileuszowe ku czci ks. prof. Romana Murawskiego SDB, red. Piotr Tomasik, 53-73. Warszawa: Wydawnictwo Salezjańskie, 2005.

Długosz, Antoni, Beata Stypułkowska. Wprowadzenie do dydaktyki biblijnej. Kraków: Wydawnictwo Naukowe Papieskiej Akademii Teologicznej, 2000.

Hajduk, Andrzej, Zbigniew Marek. „Zasada wierności Bogu i wierności człowiekowi w polskiej katechezie". Seminare 17 (2001): 33-46.

Katecheza Kościoła w świecie. Dyrektorium ogólne o katechizacji. Kraków: Wydawnictwo WAM, 1999.

Kostkiewicz, Janina. Kierunki i koncepcje pedagogiki katolickiej w Polsce 1918-1939. Kraków: Oficyna Wydawnicza „Impuls”, 2013. 
Kubik, Władysław. „Proces przemian w polskiej katechetyce drugiej połowy XX wieku". W: Kerygma. Biblia. Katecheza, red. Ryszard Czekalski, 59-81. Warszawa: Wydawnictwo Uniwersytetu Kardynała Wyszyńskiego, 2012.

Kubik, Władysław. Rozwój myśli dydaktycznej w polskiej literaturze katechetycznej w latach 1895-1970. Warszawa: Akademia Teologii Katolickiej, 1987.

Marek, Zbigniew. Podstawy i założenia katechetyki fundamentalnej. Kraków: Wydawnictwo WAM, 2007.

Nosek, Tadeusz. „Katechetyczne umacniane i rozwijanie tożsamości chrześcijańskiej”. W: Pedagogika wiary. Ksiażka dedykowana księdzu Profesorowi Zbigniewowi Markowi SJ w 60. rocznice urodzin i 35. rocznicę kapłaństwa, red. Andrzej Hajduk, Janusz Mółka, 311-322. Kraków: Wydawnictwo WAM, 2007.

Offmański, Andrzej. „Charytański Jan”. W: Stownik katechetyków polskich XX wieku, red. Ryszard Czekalski, 33-38. Warszawa: Wydawnictwo Salezjańskie, 2003.

Offmański, Andrzej. „Z pokolenia nieustannie poszukujących. Wkład Jana Charytańskiego SJ w odnowę i rozwój polskiej katechezy". W: Sto lat polskiej katechezy. Wkład wybitnych polskich katechetyków w odnowę i rozwój polskiej katechezy, red. Ryszard Czekalski, 158-177. Kraków: Wydawnictwo WAM, 2001.

Rozen, Barbara. „Wojtukiewicz Józef (1901-1989)”. W: Stownik katechetyków polskich XX wieku, red. Ryszard Czekalski, 274-276. Warszawa: Wydawnictwo Salezjańskie, 2003.

Rynio, Alina. „Katolicka myśl pedagogiczna. Próba syntezy”. W: Pedagogika katolicka. Zagadnienia wybrane, red. Alina Rynio, 411-417. Stalowa Wola: Oficyna Wydawnicza Fundacji Uniwersyteckiej w Stalowej Woli, 1999.

Stownik katechetyków polskich XX wieku, red. Ryszard Czekalski. Warszawa: Wydawnictwo Salezjańskie, 2003.

Teologu polski, co sądzisz o swojej twórczości?, red. Stanisław Celestyn Napiórkowski. Niepokalanów: Wydawnictwo Ojców Franciszkanów, 2007.

Tomasik, Piotr. „Podręcznik w edukacji religijnej młodzieży”. W: Dydaktyka w stużbie katechezy, red. Stanisław Dziekoński, 248-267. Kraków: Wydawnictwo WAM, 2002.

Walulik, Anna. Katecheza inicjacyjna w polskich katechizmach (1945-1990). Kraków: Wydawnictwo WAM, 2002. 